\title{
Peritoneal expression of matrilysin helps identify early post-operative recurrence of colorectal cancer
}

\author{
Giuseppe S. Sica ${ }^{1,2}$, Cristina Fiorani ${ }^{1}$, Carmine Stolfi ${ }^{1}$, Giovanni Monteleone ${ }^{1}$, \\ Eleonora Candi ${ }^{1}$, Ivano Amelio ${ }^{3}$, Valeria Catani ${ }^{1}$, Simone Sibio ${ }^{1}$, Andrea Divizia ${ }^{1}$, \\ Giorgia Tema $^{1}$, Edoardo Iaculli ${ }^{1}$, Achille L. Gaspari ${ }^{1}$ \\ ${ }^{1}$ Department of Experimental Medicine and Surgery, Tor Vergata University, Rome, Italy \\ ${ }^{2}$ European Society Degenerative Disease (ESDD). www.esdd.it \\ ${ }^{3}$ Medical Research Council, Toxicology Unit, Leicester, UK
}

Correspondence to:

Giuseppe S. Sica, e-mail: sigisica@gmail.com

Received: November 12, $2014 \quad$ Accepted: November 27, 2014

Published: January 21, 2015

\section{ABSTRACT}

Recurrence of colorectal cancer (CRC) following a potentially curative resection is a challenging clinical problem. Matrix metalloproteinase-7 (MMP-7) is overexpressed by CRC cells and supposed to play a major role in CRC cell diffusion and metastasis. MMP-7 RNA expression was assessed by real-time PCR using specific primers in peritoneal washing fluid obtained during surgical procedure. After surgery, patients underwent a regular follow up for assessing recurrence. transcripts for MMP-7 were detected in $31 / 57$ samples $(54 \%)$. Patients were followed-up (range 20-48 months) for recurrence prevention. Recurrence was diagnosed in 6 out of 55 patients $(11 \%)$ and two patients eventually died because of this. Notably, all the six patients who had relapsed were positive for MMP-7. Sensitivity and specificity of the test were $100 \%$ and $49 \%$ respectively. Data from patients have also been corroborated by computational approaches. Public available coloncarcinoma datasets have been employed to confirm MMP7 clinical impact on the disease. Interestingly, MMP-7 expression appeared correlated to Tgfb-1, and correlation of the two factors represented a poor prognostic factor. This study proposes positivity of MMP-7 in peritoneal cavity as a novel biomarker for predicting disease recurrence in patients with CRC.

\section{INTRODUCTION}

Colorectal cancer (CRC) is the second most commonly diagnosed solid malignancy in women and the third most common in men worldwide, accounting for over 600,000 deaths in 2008 [1-9]. In the United States, CRC is the second leading cause of cancer death accounting for approximately $9 \%$ of deaths related to cancer overall [10]. Adenocarcinoma represents the vast majority of $\mathrm{CRC}$ and $70 \%$ of all malignant tumors of gastrointestinal tract. One in three people who develop CRC will die because of it and approximately $20 \%$ will develop metastatic CRC [11-13].

The prognosis of CRC patients depends on the histologic type, cell differentiation, TNM stage and the patient's chances of being subjected to radical surgery. For patients who presents with macroscopic peritoneal metastases, treatment options are limited. Hypertermic intraperitoneal chemiotherapy (HIPEC) associated to aggressive tumor debulking surgery has been proposed in subset of patients [14-21]. Detection of tumor cells within the peritoneal cavity at the time of surgery has been proposed to identify patients with poorer outcome overall. Positive free cancer cells in the peritoneal cavity (IFTC) can be detected in a variable percentage of CRC patients at the time of surgery [22, 23]. The current available methods for IFTC identification include conventional cytology, immunohistochemistry or real-time PCR for the cytokeratin 20 (KRT-20) or carcinoembryonic antigen (CEA). However the presence of IFTC is not currently used as a prognostic factor due to the heterogeneity in sampling and analysis among different studies. This is likely due to the lack of a standard method that allows IFTC identification with sufficient accuracy. 
Several factors have been implicated in CRC prognosis [24-31], including cell cycle/apoptotic regulators [32-49], cellular motility factors [50-61] and metabolic enzymes [62-74]. For example, mutations of the tumour suppression factors p53 [75-78] have been described in about $40 \%$ to $50 \%$ of colorectal carcinomas. $\mathrm{LOH}$ of the short arm of chromosome 17 is also found in most of these tumors and are associated with aggressive tumors. [79-83] Besides the loss of function of wt p53 [54, 84-94], mutant p53 retains additional ability to promote tumorigenicity and tumor progression, giving rise to what it has been defined gain-of-function of mp53 [78, 95]. Metallopeptidases are also been involved in tumourigenesis, in particular in late stages such as invasion and metastasis [96-98], underlining their importance for recurrence and consequence recovery from the disease. In CRC [99-104], metalloproteinases are secreted as inactive enzyme and are activated extracellularly. These enzymes, in particular MMP-1, $-2,-3 .-7,-9,-13$, have been demonstrated to be expressed in human colorectal cancers. Often, the degree of over expression of some of them has been positively associated with stage of disease and/ or poor prognosis. Polymorphisms in promoter regions of MMP genes might be related to the susceptibility of digestive cancers, with a role in cancer development for MMP1 and MMP7, and a role of protection against cancer for MMP2 and MMP9 [105]. Accordingly, high level of MMP7 has been hystochemically detected in CRC and revealed in serum of CRC patients [106]. It is interesting to note that it is still an unresolved point whether MMPs are produced by cells surrounding a tumor or by the colorectal cancer cells themselves. In our study the real time PCR for a matrixmetalloproteinase 7 (MMP-7) is employed. MMP are a family of zinc-dependent endopeptidases with proteolytic activity. MMP-7 or matrilysinis is not expressed by normal colonic epithelial cells, but it is highly expressed at high levels by colonic neoplastic cells. In this particular case, the presence of a mutation in the APC gene causes accumulation of beta-Catenin/TCF complex in the nucleus, and as a consequence, up regulation of MMP-7 expression. MMP-7 targets laminina-5/laminina-332 (LN5), an important component of the basement membrane and epithelial cell adhesion that guarantees the formation of hemidesmosomes. Due to this action, MMP-7 is involved in the degradation of extracellular matrix (ECM), adaptation of tumour microenvironment [107-110] and thereby promoting the process of invasion and metastasis. Highlighting the expression of this enzyme we are able to identify, among all the IFTC, those that have greater capacity for engraftment $[84,111,112]$. In a recent study was demonstrated the diagnostic value of serum MMP-7 levels in bladder cancer $[113,114]$.

This study was aimed at determining whether MMP-7 is detectable in the peritoneal cavity of CRC patients undergoing potentially curative resection and assessing whether MMP-7 positively marks patients that eventually develop CRC recurrence.

\section{RESULTS}

\section{Peritoneal expression of $\mathrm{mmp} 7$ in colorectal cancer}

Sixty-seven peritoneal washing were performed in 67 patients who underwent surgery for colon and intraperitoneal rectal cancer. The first 10 lavages were needed to set the methodology whereas the subsequent 47 samples were the object of the study and used to assess MMP-7 expression by real-time PCR. MMP-7 transcripts were detected in 31/57 samples (54\%) (Fig. 1)

At surgery, curative resection was achieved in 56 patients. In one patient, the primary tumor was not excised because of peritoneal carcinomatosis and liver metastases. Apart from this latter case, synchronous liver metastases were present in another three patients. One patient showed peritoneal dissemination at surgery and underwent local peritonectomy. Patients demographics, tumor location, histological type, tumor grading and stage are reported in tab 1.

Patients were followed up for a mean period of 34 months (range 20-48 months). Two patients were lost at the follow up. Six of 56 patients undergone colonic resection, eventually presented with tumor recurrence (10.7\%). Type of recurrence are presented in tab 2. Six patients died

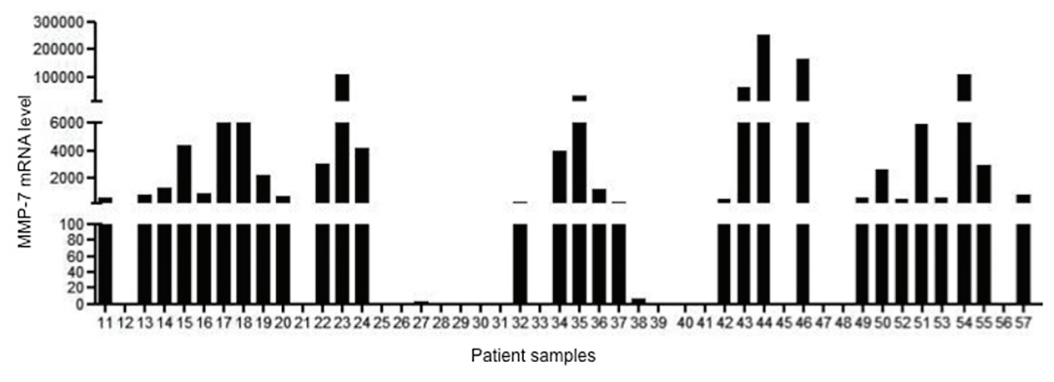

Figure 1: Expression of MMP-7 RNA transcripts in 47 peritoneal washing samples taken from 47 patients who had undergone surgery for colorectal cancer. 
Table 1: Patients demographics and tumor characteristics

\begin{tabular}{|c|c|c|c|c|c|c|c|c|}
\hline \multicolumn{3}{|c|}{ Tumor type and demographics } & \multicolumn{3}{|c|}{ n. } & \multicolumn{3}{|c|}{$\%$} \\
\hline \multicolumn{9}{|c|}{ Gender } \\
\hline \multicolumn{3}{|l|}{ M } & \multicolumn{3}{|c|}{19} & \multicolumn{3}{|c|}{33} \\
\hline \multicolumn{3}{|l|}{$\mathrm{F}$} & \multicolumn{3}{|c|}{38} & \multicolumn{3}{|c|}{67} \\
\hline \multicolumn{9}{|c|}{ Age (mean 68 [range 37-91]) } \\
\hline \multicolumn{3}{|l|}{$>60$} & \multicolumn{3}{|c|}{43} & \multicolumn{3}{|c|}{75} \\
\hline \multicolumn{3}{|l|}{$<60$} & \multicolumn{3}{|c|}{14} & \multicolumn{3}{|c|}{25} \\
\hline \multicolumn{9}{|c|}{ Localization } \\
\hline \multicolumn{3}{|l|}{ right } & \multicolumn{3}{|c|}{22} & \multicolumn{3}{|c|}{39} \\
\hline \multicolumn{3}{|c|}{ transverse } & \multicolumn{3}{|c|}{2} & \multicolumn{3}{|c|}{3} \\
\hline \multicolumn{3}{|c|}{ left } & \multicolumn{3}{|c|}{25} & \multicolumn{3}{|c|}{44} \\
\hline \multicolumn{3}{|l|}{ rectum } & \multicolumn{3}{|c|}{8} & \multicolumn{3}{|c|}{14} \\
\hline \multicolumn{9}{|c|}{ Histology } \\
\hline \multicolumn{3}{|c|}{ adenocarcinoma } & \multicolumn{3}{|c|}{52} & \multicolumn{3}{|c|}{91} \\
\hline \multicolumn{3}{|c|}{ mucinous } & & 5 & & & 9 & \\
\hline Grading & $\begin{array}{l}\text { Stage } \\
\text { (UICC) }\end{array}$ & (Dukes) & & & & & & \\
\hline G1 & I & A & 7 & 18 & 1 & 12 & 32 & 2 \\
\hline $\mathrm{G} 2$ & II & $\mathrm{B}(1-2)$ & 33 & 20 & 1126 & 58 & 35 & 1946 \\
\hline G2-G3 & III & $\mathrm{C}(1-2)$ & 12 & 15 & 015 & 21 & 26 & 026 \\
\hline G3 & IV & D & 5 & 4 & 4 & 9 & 7 & 7 \\
\hline
\end{tabular}

Table 2: Cause of death and type of recurrence

\begin{tabular}{|l|l|}
\hline Death: & 1 \\
\hline Inoperable (liver mets + carcinomatosis) & 2 \\
\hline Recurrence & \\
\hline Bone and lungmets & \\
\hline Local recurrence & 1 \\
\hline Syncronous liver mets & 2 \\
\hline Non cancerous death & \multicolumn{2}{|l|}{} \\
\hline Recurrence: & 1 \\
\hline Peritoneal carcinomatosis & 2 \\
\hline Local recurrence & 3 \\
\hline Distant metastasis & 3 \\
\hline
\end{tabular}

during follow up:one is the patients found inoperable; one within the patients with synchronous metastases; two patients died because of their relapse; the other two deaths occurred because of surgical complication in one case and because of ageing in the second patient. Deaths are also reported in tab 2 .
Within the 3 patients that had liver metastases preoperatively; 2 patients who had developed recurrence ( 1 to lung and bones and 1 local at anastomotic site).

Notably, MMP-7 was expressed in all the 6 patients who had relapsed, thus showing a sensitivity of $100 \%$, whereas the specificity of the method is $49 \%$. 


\section{MMP7 in colon carcinoma}

In order to identify a potential clinical relevance for MMP7 in human coloncarcinoma we screened publicity available human adenocarcinoma datasets for different hystopathological and prognostic parameters. Basic expression analysis of MMP7 revealed that its mRNA levels are specifically upregulated in colon malignancies when compared to normal colon epithelial tissues. Colon carcinomas showed an upregulation between 3.8 and 7.1 depending on the dataset analyzed and the variety of the pool of samples (Fig. 2). When datasets with clinical parameters were selected for the analysis, stratification for tumour grade or recurrence further identified MMP7 selective expression. Indeed MMP7 expression levels resulted enriched in tumour with high grade (tumour grade 3 ) and in patients, which encountered recurrence within 3 years from the primary tumour onset (Fig. 3). This analysis highlighted the efficacy of MMP7 to specifically subselect tumours with higher aggressiveness, suggesting a potential role of negative prognostic marker. To further characterize MMP7 positive expressing colon carcinomas and to go insight a potential mechanism for MMP7 function in these tumours, we performed an expression analysis for MMP73 and putative coexpressed factors. Among the top rated genes we identified transforming growth factor beta 1 (TGFb1) as a statistically significant coexpressed factors with MMP7 (Correlation factors 0.4) (Fig. 4A). Notably 5 normal colon samples do not show expression neither MMP7 nor TGFb1. TGF-beta 1 plays a role as a tumor suppressor in early disease [115-122] and has prooncogenic effects as well as drug-resistance [123-136] in advanced tumor stage $[121,123,137,138]$, in particular in metastasis process [139-143]. Therefore MMP7/TGFb1 coexpression in advanced coloncarcinomas would suggest a potential synergistic negative impact of these two factors on the clinical outcome. To assess the impact of MMP7/ TGFb1 on patient survival we performed a computation analysis, stratifying the samples in two groups: samples where MMP7 and TGFb1 positively correlate ("gene interaction") and samples where they do not correlate ("no gene interaction"). Computation estimation of KaplanMaier in these two subgroups revealed that coexpression of MMP7 and TGFb1 negatively affected survival outcome of colon carcinoma patients (Fig. 4B)
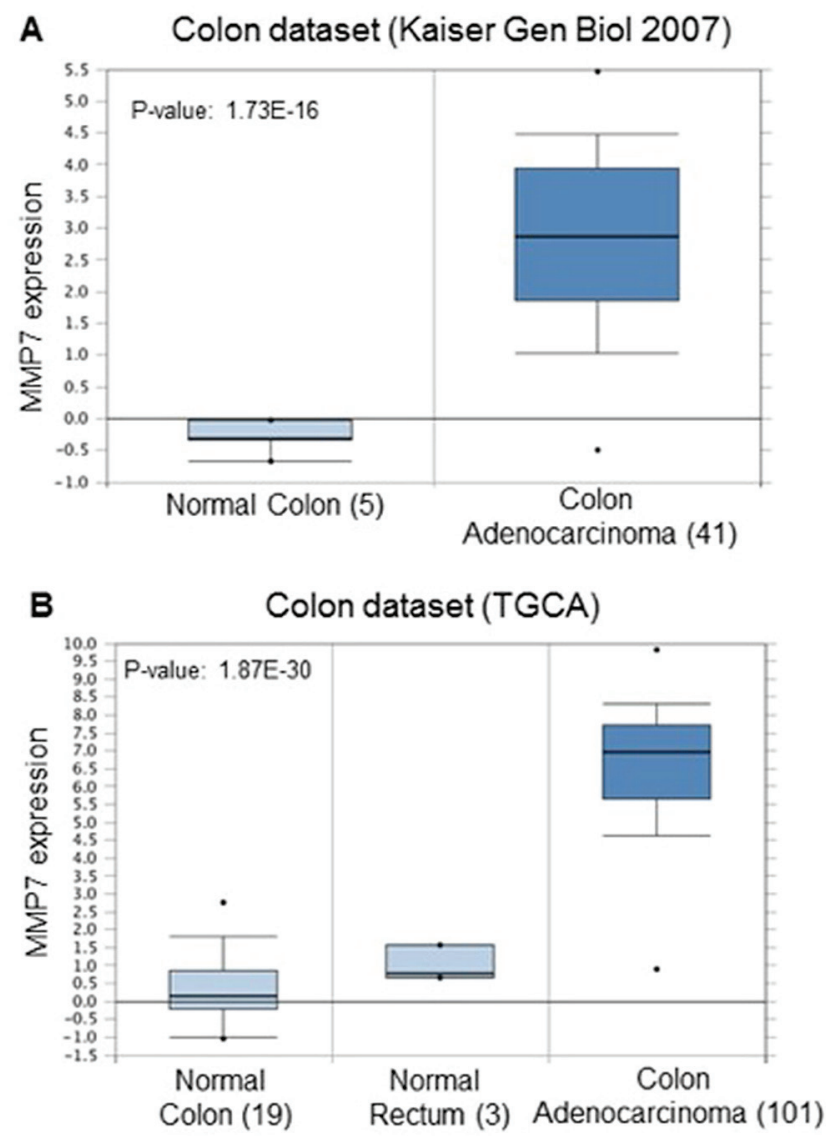

Figure 2: (A, B) Comparison of MMP7 expression level in colon carcinomas and Normal colon or rectum epithelia in different datasets. MMP7 mRNA levels are upregulated in malignant lesions compared to normal counterparts. Numbers in brackets indicate number of sample analyzed in each group. $P$ value: 1.73E-16 (A) and 1.87E-30 (B) oncomine.org. 

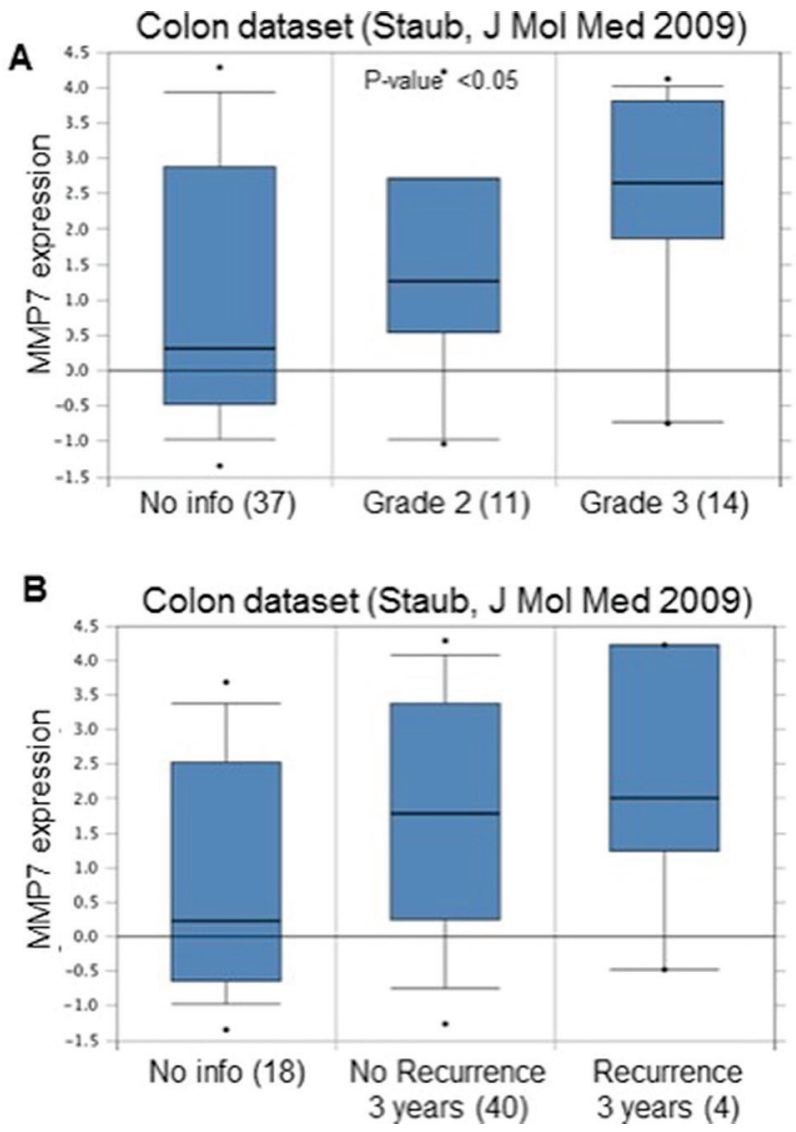

Figure 3: (A) MMP7 is upregulated in high-grade colon carcinomas. Grade 3 tumours showed increased mRNA levels compared to Grade 2. $P$-value 0.05 . Numbers in brackets indicate number of sample analyzed in each group. No info indicates samples without tumour grade information. (B) MMP7 is upregulated in colon carcinoma patients with recurrence within the first 3 years. $P$-value 0.05 . Numbers in brackets indicate number of sample analyzed in each group. No info indicates samples without recurrence information. oncomine.org.

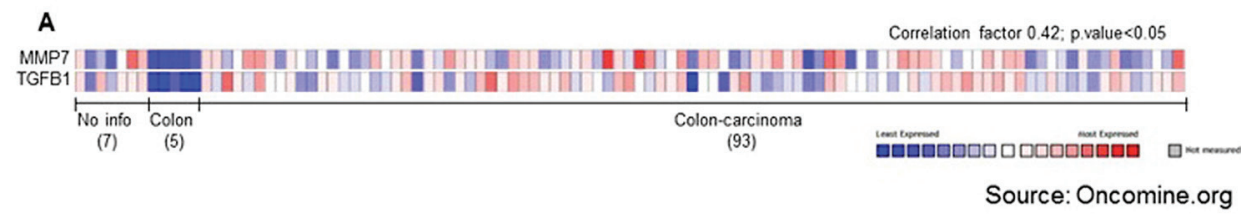

MMP7/TGFB1 correlation predicts bad survival

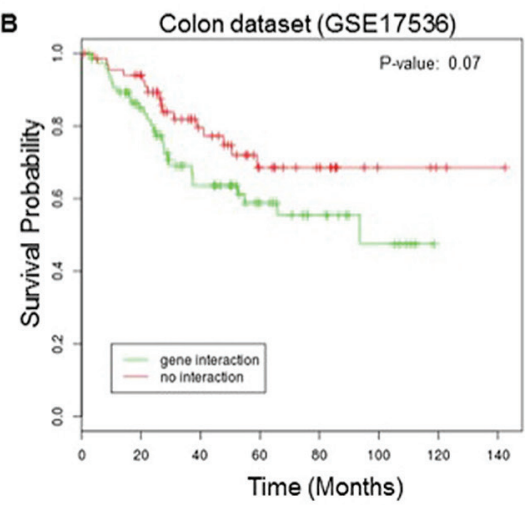

Figure 4: (A) Coexpression analysis revealed direct correlation between MMP7 and TGFb1. Correlation factor $0.42, p$ value $<0.05$ oncomine. org. (B) 4 Positive MMP7/TGFB1 correlation represents a prognostic factor for bad patient survival. Patient survival estimation of MMP7/ TGFB1 positive correlation group ("gene interaction") compared to negative or absent correlation group ("no interaction"). $P$ value $=0.07$. 


\section{DISCUSSION}

The TNM system is of basic prognostic value in solid tumor. Peritoneal carcinomatosis means metastatic disease, and curative resection is only seldom possible. The role of peritoneal cytology in gynecology is well defined, and it is formally incorporated into the TNM staging for ovarian and endometrial cancer [144-153]. Positive peritoneal washing represent an independent prognostic factor for poor survival also in patients with cancer of the gastrointestinal tract [154]. Peritoneal lavage in search for IFTC can be part of the staging protocol in case for pancreatic adenocarcinoma, and for cancer of the cardia or stomach. [155-158] In CRC, the occurrence of isolated tumor cells in the peritoneal washings could be correlated with a worse prognosis, even in early stages. Furthermore, if it is clear that the serosal cancer cells can implant within the peritoneum [159], it has been shown that they have the potential to enter both the lymphatics and the systemic circulation, thus showing a more aggressive and motile phenotype [107, 160-163].

Therefore, the presence of IFTC could serve as prognostic marker to guide adjuvant therapy [164].

Cytopathology, immunocytochemistry (ICC) and polymerase chain reaction (PCR) are the different methods in use for defining the presence of neoplastic cells in the peritoneum at the time of colorectal cancer surgery. The wide range in positive lavage across studies illustrates the difficulty in comparing studies with different methods of detection of positive lavage fluid. The overall mean rate of positive lavage is $13.7 \%$ [165]. Conventional staining (Papanicolau, PAS, Giemsa) techniques are relatively inexpensive and do not requires preservation of RNA. ICC, also a histological staining technique, appears to result in a far greater yield of IFTC thancytopathology [166-168]. In fact, in cytological examinations of peritoneal fluid, the distinction of mesothelial cells and tumor cells might be difficult. It is crucial to detect epithelial cells; however, ICC is subjective and depends on the strength of cellular staining $[169,170]$. PCR-based methods are suitable for detecting minute quantities of intraperitoneal free cancer cells but, as they detect DNA and not viable cells, there is a problem in differentiate cancerous cells from non-malignant cells or cellular debris [171]. The most commonly used markers, specific for cancer cells, are the CEA and the CK-20 for gastric and colorectal cancer $[155,156]$, and the C1P83, CA 19-9, 17-1-A, C54-0, KL-1 for pancreatic adenocarcinoma $[157,172]$. There is no data related to endometrial and ovarian cancers because the single cell analysis is still the method of choice.

We have used a use a newly employed marker gene, expressed in all cancer cells and not detectable in any nontumor cells, the MMP-7 [173].

This gene plays a crucial role in tumor invasion and metastatic capacity. MMP-7 is not generally expressed in normal differentiated epithelial colon cells, but is found up regulated in CCR cells where is investigated for its metastatic potentiality. Up-regulation of MMP-7 occurs very early in colonic epithelial cells and has been found in $85 \%$ of colorectal adenocarcinomas and associated with a poor prognosis. In this series, MMP-7 is expressed in all patients who had relapsed, thus showing a sensitivity of $100 \%$. The specificity is far lower (49\%) and this is the major drawback of the methodic in use, because the test doesn't discriminate between colorectal and other cells such us mesothelium cells. However, cytology and immunochemistry could be helpful in differentiating colonic cells from others. The bioinformatics data highlighted the efficacy of MMP7 to specifically subselect tumours with higher aggressiveness, suggesting a potential role of negative prognostic marker. In addition strikingly MMP-7 appeared correlated to tgfb- 1 . The correlation might probably potentiate the metastatic propensity of the cells, thus affecting progression of the disease and survival expectation. However, additional studies will be required to assess the cause/effect relationship between these two factors.

In conclusion, positivity of MMP-7 in peritoneal cavity samples could be a novel biomarker for predicting disease recurrence in patients with CRC.

\section{MATERIALS AND METHODS}

\section{Patients and preparation of peritoneal washing}

Between November 2009 and November 2011, all the patients undergoing elective resection for cancer of the colon or intra-peritoneal rectum were enrolled in this prospective longitudinal study. Exclusion criteria were preoperative chemo- o radiotherapy and cancer of the low rectum.

\section{Procedure}

Peritoneal washing is done just after the laparotomy or laparoscopy, before colonic mobilization. One-hundred twenty $\mathrm{ml}$ of saline solution at $20^{\circ} \mathrm{C}$ is instilled at the site of the tumor and $60 \mathrm{ml}$ of this fluid is then aspirated and collected in sterile containers and sent for RNA extraction. Samples are centrifuged at $670 \mathrm{G}$ for 10 minutes. RNA is extracted from the cell precipitate using the TRIzol reagent (Invitrogen), reverse transcribed into complementary DNA (cDNA) and amplified by Real-time PCR using the following conditions: denaturation, 1 minute at $95^{\circ} \mathrm{C}$; hybridization, 30 seconds at $50^{\circ} \mathrm{C}$; and finally elongation of the filament at $75^{\circ} \mathrm{C}$ for 30 seconds. During PCR, temperature variations are used to control the activity of the polymerase and the binding of the primers. The sequence of the primers for the MMP-7 is FWD: 5'-ATGAACGCTGGACGGATGGT-3; REV: 5'-TGGAGTGGAGGAACAGTGCT-3'. The sequence of the primers for $\beta$-actin, used as an internal control, is: FWD: 5'-AAGATGACCCAGATCATGTTTGAG ACC-3; REV: 5'-AGCCAGTCCAGACGC AGGAT-3. 
The entire method is performed using the 'IQ SYBR Green Supermix' (Bio-Rad Laboratories, Milan). Each sample was analyzed in duplicate by Real-time PCR. A sample was considered positive for the gene analyzed when adequate amplification curve was detected in the dual evaluation conducted on the same sample. Samples were considered negative when no amplified or only one amplified was detected. This method, based on duplicate analysis, allows reducing to a negligible value the probability that the amplified does not correspond in fact to the gene under study.

\section{Follow-up}

After surgical resection, all patients are undergoing regular follow-up for assessing recurrence. Postoperative surveillance includes onco-markers, CT scan and colonoscopy.

\section{Bioinformatic}

Gene expression datasets were analysed by using oncomine online tool (onocomine.org). Analysis of KaplanMaier estimation curve has been performed as previously described [174, 175]. Briefly, samples were divided in two cohorts so that to maximize positive correlation between expression profiles of MMP7 and TGFb1. The separation of patients into "cohort 1" and "cohort 2" along with survival information is next used to find any statistical differences in survival outcome. The R statistical package is used to perform survival analyses ${ }^{1}$ and to draw KMplots.

\section{ACKNOWLEDGMENTS}

This study was supported by the European Society degenerative Disease (ESDD, www.esdd.it) (GS).

\section{REFERENCES}

1. Jemal A, Bray F, Center MM, Ferlay J, Ward E, Forman D. Global cancer statistics. CA: a cancer journal for clinicians. 2011; 61:69-90.

2. Amos-Landgraf JM, Clipson L, Newton MA, Dove WF. The many ways to open the gate to colon cancer. Cell cycle. 2012; 11:1261-1262.

3. Soncini D, Caffa I, Patrone F, Ballestrero A, Nencioni A. Synthetic lethality-based therapeutics: perspectives for applications in colorectal cancer. Current cancer drug targets. 2012; 12:329-338.

4. Luo H, Yang Y, Duan J, Wu P, Jiang Q, Xu C. PTENregulated $\mathrm{AKT} / \mathrm{FoxO} \mathrm{a} / \mathrm{Bim}$ signaling contributes to reactive oxygen species-mediated apoptosis in selenite-treated colorectal cancer cells. Cell death \& disease. 2013; 4:e481.

5. Peiser J, Smith A, Bapat B, Stern H. Colorectal tumourigenesis. Surgical oncology. 1994; 3:195-201.

6. Marques C, Oliveira CS, Alves S, Chaves SR, Coutinho OP, Corte-Real M, Preto A. Acetate-induced apoptosis in colorectal carcinoma cells involves lysosomal membrane permeabilization and cathepsin D release. Cell death \& disease. 2013; 4:e507.

7. Slaby O, Sobkova K, Svoboda M, Garajova I, Fabian P, Hrstka R, Nenutil R, Sachlova M, Kocakova I, Michalek J, Smerdova T, Knoflickova D, Vyzula R. Significant overexpression of Hsp110 gene during colorectal cancer progression. Oncology reports. 2009; 21:1235-1241.

8. Simpson KL, Cawthorne C, Zhou C, Hodgkinson CL, Walker MJ, Trapani F, Kadirvel M, Brown G, Dawson MJ, MacFarlane M, Williams KJ, Whetton AD, Dive C. A caspase-3 'death-switch' in colorectal cancer cells for induced and synchronous tumor apoptosis in vitro and in vivo facilitates the development of minimally invasive cell death biomarkers. Cell death \& disease. 2013; 4:e613.

9. Lascano V, Zabalegui LF, Cameron K, Guadagnoli M, Jansen M, Burggraaf M, Versloot M, Rodermond H, van der Loos C, Carvalho-Pinto CE, Kalthoff H, Medema JP, Hahne M. The TNF family member APRIL promotes colorectal tumorigenesis. Cell death and differentiation. 2012; 19:1826-1835.

10. Siegel R, Naishadham D, Jemal A. Cancer statistics, 2013. CA: a cancer journal for clinicians. 2013; 63:11-30.

11. Golan T, Urban D, Berger R, Lawrence YR. Changing prognosis of metastatic colorectal adenocarcinoma: Differential improvement by age and tumor location. Cancer. 2013; 119:3084-3091.

12. Kamarajugadda S, Cai Q, Chen H, Nayak S, Zhu J, He M, Jin Y, Zhang Y, Ai L, Martin SS, Tan M, Lu J. Manganese superoxide dismutase promotes anoikis resistance and tumor metastasis. Cell death \& disease. 2013; 4:e504.

13. Demidov ON, Zhu Y, Kek C, Goloudina AR, Motoyama N, Bulavin DV. Role of Gadd45a in Wip1-dependent regulation of intestinal tumorigenesis. Cell death and differentiation. 2012; 19:1761-1768.

14. Werneck MB, Hottz E, Bozza PT, Viola JP. Cyclosporin A inhibits colon cancer cell growth independently of the calcineurin pathway. Cell cycle. 2012; 11:3997-4008.

15. Collard TJ, Urban BC, Patsos HA, Hague A, Townsend PA, Paraskeva C, Williams AC. The retinoblastoma protein $(\mathrm{Rb})$ as an anti-apoptotic factor: expression of $\mathrm{Rb}$ is required for the anti-apoptotic function of BAG-1 protein in colorectal tumour cells. Cell death \& disease. 2012; 3:e408.

16. Esquivel J, Sticca R, Sugarbaker P, Levine E, Yan TD, Alexander R, Baratti D, Bartlett D, Barone R, Barrios P, Bieligk S, Bretcha-Boix P, Chang CK, Chu F, Chu Q, Daniel S, et al. Cytoreductive surgery and hyperthermic intraperitoneal chemotherapy in the management of peritoneal surface malignancies of colonic origin: a consensus statement. Society of Surgical Oncology. Annals of surgical oncology. 2007; 14:128-133.

17. Sridharan M, Hubbard JM, Grothey A. Colorectal cancer: how emerging molecular understanding affects treatment decisions. Oncology. 2014; 28:110-118. 
18. Karaayvaz M, Zhai H, Ju J. miR-129 promotes apoptosis and enhances chemosensitivity to 5-fluorouracil in colorectal cancer. Cell death \& disease. 2013; 4:e659.

19. Bullock MD, Pickard KM, Nielsen BS, Sayan AE, Jenei V, Mellone M, Mitter R, Primrose JN, Thomas GJ, Packham GK, Mirnezami AH. Pleiotropic actions of miR-21 highlight the critical role of deregulated stromal microRNAs during colorectal cancer progression. Cell death \& disease. 2013; 4:e684.

20. Debunne H, Ceelen W. Mucinous differentiation in colorectal cancer: molecular, histological and clinical aspects. Acta chirurgica Belgica. 2013; 113:385-390.

21. Huang CY, Kuo WT, Huang YC, Lee TC, Yu LC. Resistance to hypoxia-induced necroptosis is conferred by glycolytic pyruvate scavenging of mitochondrial superoxide in colorectal cancer cells. Cell death \& disease. 2013; 4:e622.

22. Altomare DF, Tedeschi M, Rotelli MT, Bocale D, Piscitelli D, Rinaldi M. Lack of prognostic role of pre- and postoperative peritoneal cytology and cytokeratin PCR-expression on local recurrence after curative anterior resection for mid-low rectal cancer. Updates in surgery. 2011; 63:109-113.

23. He MF, Wang S, Wang Y, Wang XN. Modeling cell-incell structure into its biological significance. Cell death \& disease. 2013; 4:e630.

24. Bertrand FE, Angus CW, Partis WJ, Sigounas G. Developmental pathways in colon cancer: crosstalk between WNT, BMP, Hedgehog and Notch. Cell cycle. 2012; 11:4344-4351.

25. Markert EK, Levine AJ, Vazquez A. Proliferation and tissue remodeling in cancer: the hallmarks revisited. Cell death \& disease. 2012; 3:e397.

26. Brenner H, Kloor M, Pox CP. Colorectal cancer. Lancet. 2014; 383:1490-1502.

27. Shimoyama S, Yamasaki K, Kawahara M, Kaminishi M. Increased serum angiogenin concentration in colorectal cancer is correlated with cancer progression. Clinical cancer research: an official journal of the American Association for Cancer Research. 1999; 5:1125-1130.

28. Mazurek N, Byrd JC, Sun Y, Hafley M, Ramirez K, Burks J, Bresalier RS. Cell-surface galectin-3 confers resistance to TRAIL by impeding trafficking of death receptors in metastatic colon adenocarcinoma cells. Cell death and differentiation. 2012; 19:523-533.

29. Brenner H, Werner S, Chen H. Multitarget stool DNA testing for colorectal-cancer screening. The New England journal of medicine. 2014; 371:184-185.

30. Sun S, Klebaner F, Tian T. A new model of time scheme for progression of colorectal cancer. BMC systems biology. 2014; 8:S2.

31. Sullivan S, Tosetto M, Kevans D, Coss A, Wang L, O'Donoghue D, Hyland J, Sheahan K, Mulcahy H, O'Sullivan J. Localization of nuclear cathepsin L and its association with disease progression and poor outcome in colorectal cancer. International journal of cancer Journal international du cancer. 2009; 125:54-61.

32. Orzaez M, Guevara T, Sancho M, Perez-Paya E. Intrinsic caspase- 8 activation mediates sensitization of erlotinibresistant tumor cells to erlotinib/cell-cycle inhibitors combination treatment. Cell death \& disease. 2012; 3:e415.

33. Sui X, Kong N, Ye L, Han W, Zhou J, Zhang Q, He C, Pan H. p38 and JNK MAPK pathways control the balance of apoptosis and autophagy in response to chemotherapeutic agents. Cancer letters. 2014; 344:174-179.

34. Ma B, Zhang H, Wang J, Zhang B, Xu X, Cheng B. HIV-1 viral protein $\mathrm{R}(\mathrm{Vpr})$ induction of apoptosis and cell cycle arrest in multidrug-resistant colorectal cancer cells. Oncology reports. 2012; 28:358-364.

35. Ehrhardt H, Wachter F, Grunert M, Jeremias I. Cell cyclearrested tumor cells exhibit increased sensitivity towards TRAIL-induced apoptosis. Cell death \& disease. 2013; 4:e661.

36. Garrison SP, Phillips DC, Jeffers JR, Chipuk JE, Parsons MJ, Rehg JE, Opferman JT, Green DR, Zambetti GP. Genetically defining the mechanism of Puma- and Bim-induced apoptosis. Cell death and differentiation. 2012; 19:642-649.

37. Boren J, Brindle KM. Apoptosis-induced mitochondrial dysfunction causes cytoplasmic lipid droplet formation. Cell death and differentiation. 2012; 19:1561-1570.

38. McDermott U, Longley DB, Galligan L, Allen W, Wilson T, Johnston PG. Effect of p53 status and STAT1 on chemotherapy-induced, Fas-mediated apoptosis in colorectal cancer. Cancer research. 2005; 65:8951-8960.

39. Imao T, Nagata S. Apaf-1- and Caspase-8-independent apoptosis. Cell death and differentiation. 2013; 20:343-352.

40. Liu B, Gao HC, Xu JW, Cao H, Fang XD, Gao HM, Qiao SX. Apoptosis of colorectal cancer UTC116 cells induced by Cantharidinate. Asian Pacific journal of cancer prevention: APJCP. 2012; 13:3705-3708.

41. Wang L, Gallo KA, Conrad SE. Targeting mixed lineage kinases in ER-positive breast cancer cells leads to G2/M cell cycle arrest and apoptosis. Oncotarget. 2013; 4:1158-1171.

42. Dewson G, Ma S, Frederick P, Hockings C, Tan I, Kratina T, Kluck RM. Bax dimerizes via a symmetric BH3: groove interface during apoptosis. Cell death and differentiation. 2012; 19:661-670.

43. Bertero T, Gastaldi C, Bourget-Ponzio I, Mari B, Meneguzzi G, Barbry P, Ponzio G, Rezzonico R. CDC25A targeting by miR-483-3p decreases CCND-CDK4/6 assembly and contributes to cell cycle arrest. Cell death and differentiation. 2013; 20:800-811.

44. Mahyar-Roemer M, Kohler H, Roemer K. Role of Bax in resveratrol-induced apoptosis of colorectal carcinoma cells. BMC cancer. 2002; 2:27.

45. Christiansen AE, Ding T, Fan Y, Graves HK, Herz HM, Lindblad JL, Bergmann A. Non-cell autonomous control of apoptosis by ligand-independent Hedgehog 
signaling in Drosophila. Cell death and differentiation. 2013; 20:302-311.

46. Liu Y, Borchert GL, Surazynski A, Phang JM. Proline oxidase, a p53-induced gene, targets COX-2/PGE2 signaling to induce apoptosis and inhibit tumor growth in colorectal cancers. Oncogene. 2008; 27:6729-6737.

47. Samame Perez-Vargas JC, Biondani P, Maggi C, Gariboldi M, Gloghini A, Inno A, Volpi CC, Gualeni AV, di Bartolomeo M, de Braud F, Castano A, Bossi I, Pietrantonio F. Role of cMET in the development and progression of colorectal cancer. International journal of molecular sciences. 2013; 14:18056-18077.

48. Allagnat F, Fukaya M, Nogueira TC, Delaroche D, Welsh N, Marselli L, Marchetti P, Haefliger JA, Eizirik DL, Cardozo AK. C/EBP homologous protein contributes to cytokine-induced pro-inflammatory responses and apoptosis in beta-cells. Cell death and differentiation. 2012; 19:1836-1846.

49. Li T, Leong MH, Harms B, Kennedy G, Chen L. MicroRNA-21 as a potential colon and rectal cancer biomarker. World journal of gastroenterology: WJG. 2013; 19:5615-5621.

50. Chu K, Boley KM, Moraes R, Barsky SH, Robertson FM. The paradox of E-cadherin: role in response to hypoxia in the tumor microenvironment and regulation of energy metabolism. Oncotarget. 2013; 4:446-462.

51. Chang CC, Yang MH, Lin BR, Chen ST, Pan SH, Hsiao M, Lai TC, Lin SK, Jeng YM, Chu CY, Chen RH, Yang PC, Chin YE, Kuo ML. CCN2 inhibits lung cancer metastasis through promoting DAPK-dependent anoikis and inducing EGFR degradation. Cell death and differentiation. 2013; 20:443-455.

52. Lee S, Qiao J, Paul P, O’Connor KL, Evers MB, Chung DH. FAK is a critical regulator of neuroblastoma liver metastasis. Oncotarget. 2012; 3:1576-1587.

53. Xu L, Zhang Y, Wang H, Zhang G, Ding Y, Zhao L. Tumor suppressor miR-1 restrains epithelial-mesenchymal transition and metastasis of colorectal carcinoma via the MAPK and PI3K/AKT pathway. Journal of translational medicine. 2014; $12: 244$.

54. Kang MY, Kim HB, Piao C, Lee KH, Hyun JW, Chang IY, You HJ. The critical role of catalase in prooxidant and antioxidant function of $\mathrm{p} 53$. Cell death and differentiation. 2013; 20:117-129.

55. Dahlmann M, Sack U, Herrmann P, Lemm M, Fichtner I, Schlag PM, Stein U. Systemic shRNA mediated knock down of S100A4 in colorectal cancer xenografted mice reduces metastasis formation. Oncotarget. 2012; 3:783-797.

56. Liu K. Role of apoptosis resistance in immune evasion and metastasis of colorectal cancer. World journal of gastrointestinal oncology. 2010; 2:399-406.

57. Wang J, Ding W, Sun B, Jing R, Huang H, Shi G, Wang H. Targeting of colorectal cancer growth, metastasis, and anti-apoptosis in BALB/c nude mice via APRIL siRNA. Molecular and cellular biochemistry. 2012; 363:1-10.
58. Zhou Y, Rideout WM 3rd, Bressel A, Yalavarthi S, Zi T, Potz D, Farlow S, Brodeur J, Monti A, Reddipalli S, Xiao Q, Bottega S, Feng B, Chiu MI, Bosenberg M, Heyer J. Spontaneous genomic alterations in a chimeric model of colorectal cancer enable metastasis and guide effective combinatorial therapy. PloS one. 2014; 9:e105886.

59. Xu SL, Zeng DZ, Dong WG, Ding YQ, Rao J, Duan JJ, Liu Q, Yang J, Zhan N, Liu Y, Hu QP, Zhang X, Cui YH, Kung HF, Yu SC, Bian XW. Distinct patterns of ALDH1A1 expression predict metastasis and poor outcome of colorectal carcinoma. International journal of clinical and experimental pathology. 2014; 7:2976-2986.

60. Zhang GJ, Li Y, Zhou H, Xiao HX, Zhou T. miR20a is an independent prognostic factor in colorectal cancer and is involved in cell metastasis. Molecular medicine reports. 2014; 10:283-291.

61. Kodama H, Yamakado K, Takaki H, Suzawa N, Yamada T, Takeda K. Impact of 18F-FDG-PET/CT on treatment strategy in colorectal cancer lung metastasis before lung radiofrequency ablation. Nuclear medicine communications. 2013; 34:689-693.

62. Lyssiotis CA, Vander-Heiden MG, Munoz-Pinedo C, Emerling BM. Emerging concepts: linking hypoxic signaling and cancer metabolism. Cell death \& disease. 2012; 3:e303.

63. Mahmoudi T, Karimi K, Arkani M, Farahani H, Nobakht H, Dabiri R, Asadi A, Vahedi M, Zali MR. Lack of associations between Vitamin D metabolism-related gene variants and risk of colorectal cancer. Asian Pacific journal of cancer prevention: APJCP. 2014; 15:957-961.

64. Munoz-Pinedo C, El Mjiyad N, Ricci JE. Cancer metabolism: current perspectives and future directions. Cell death \& disease. 2012; 3:e248.

65. Branco-Price C, Evans CE, Johnson RS. Endothelial hypoxic metabolism in carcinogenesis and dissemination: HIF-A isoforms are a NO metastatic phenomenon. Oncotarget. 2013; 4:2567-2576.

66. Liu K, Czaja MJ. Regulation of lipid stores and metabolism by lipophagy. Cell death and differentiation. 2013; 20:3-11.

67. Sotgia F, Martinez-Outschoorn UE, Lisanti MP. Cancer metabolism: new validated targets for drug discovery. Oncotarget. 2013; 4:1309-1316.

68. Ferber EC, Peck B, Delpuech O, Bell GP, East P, Schulze A. FOXO3a regulates reactive oxygen metabolism by inhibiting mitochondrial gene expression. Cell death and differentiation. 2012; 19:968-979.

69. Li S, Zhao X, Wu Z, Li Y, Zhu L, Cui B, Dong X, Tian S, $\mathrm{Hu}$ F, Zhao Y. Polymorphisms in arachidonic acid metabolism-related genes and the risk and prognosis of colorectal cancer. Familial cancer. 2013; 12:755-765.

70. He Z, Liu H, Agostini M, Yousefi S, Perren A, Tschan MP, Mak TW, Melino G, Simon HU. p73 regulates autophagy and hepatocellular lipid metabolism through a transcriptional activation of the ATG5 gene. Cell death and differentiation. 2013; 20:1415-1424. 
71. Liu PP, Liao J, Tang ZJ, Wu WJ, Yang J, Zeng ZL, Hu Y, Wang P, Ju HQ, Xu RH, Huang P. Metabolic regulation of cancer cell side population by glucose through activation of the Akt pathway. Cell death and differentiation. 2014; 21:124-135.

72. Hubner RA, Muir KR, Liu JF, Sellick GS, Logan RF, Grainge M, Armitage N, Chau I, Houlston RS. Folate metabolism polymorphisms influence risk of colorectal adenoma recurrence. Cancer epidemiology, biomarkers \& prevention: a publication of the American Association for Cancer Research, cosponsored by the American Society of Preventive Oncology. 2006; 15:1607-1613.

73. Crous-Bou M, Rennert G, Salazar R, Rodriguez-Moranta F, Rennert HS, Lejbkowicz F, Kopelovich L, Lipkin SM, Gruber SB, Moreno V. Genetic polymorphisms in fatty acid metabolism genes and colorectal cancer. Mutagenesis. 2012; 27:169-176.

74. Carvalho B, Sillars-Hardebol AH, Postma C, Mongera S, Terhaar Sive Droste J, Obulkasim A, van de Wiel M, van Criekinge W, Ylstra B, Fijneman RJ, Meijer GA. Colorectal adenoma to carcinoma progression is accompanied by changes in gene expression associated with ageing, chromosomal instability, and fatty acid metabolism. Cellular oncology. 2012; 35:53-63.

75. Montero J, Dutta C, van Bodegom D, Weinstock D, Letai A. p53 regulates a non-apoptotic death induced by ROS. Cell death and differentiation. 2013; 20:1465-1474.

76. Richardson RB. p53 mutations associated with agingrelated rise in cancer incidence rates. Cell cycle. 2013; 12:2468-2478.

77. Rey C, Soubeyran I, Mahouche I, Pedeboscq S, Bessede A, Ichas F, De Giorgi F, Lartigue L. HIPK1 drives p53 activation to limit colorectal cancer cell growth. Cell cycle. 2013; 12:1879-1891.

78. Mello SS, Attardi LD. Not all p53 gain-of-function mutants are created equal. Cell death and differentiation. 2013; 20:855-857.

79. Hill R, Rabb M, Madureira PA, Clements D, Gujar SA, Waisman DM, Giacomantonio CA, Lee PW. Gemcitabinemediated tumour regression and p53-dependent gene expression: implications for colon and pancreatic cancer therapy. Cell death \& disease. 2013; 4:e791.

80. Wang B, Niu D, Lam TH, Xiao Z, Ren EC. Mapping the p53 transcriptome universe using p53 natural polymorphs. Cell death and differentiation. 2014; 21:521-532.

81. Kim NH, Cha YH, Kang SE, Lee Y, Lee I, Cha SY, Ryu JK, Na JM, Park C, Yoon HG, Park GJ, Yook JI, Kim HS. p53 regulates nuclear GSK-3 levels through miR-34-mediated Axin2 suppression in colorectal cancer cells. Cell cycle. 2013; 12:1578-1587.

82. Tavana $\mathrm{O}, \mathrm{Gu}$ W. p53 and DNA methylation suppress the TRAIN to cell death. Cell cycle. 2013; 12:9-10.

83. van Leeuwen IM, Rao B, Sachweh MC, Lain S. An evaluation of small-molecule p53 activators as chemoprotectants ameliorating adverse effects of anticancer drugs in normal cells. Cell cycle. 2012; 11:1851-1861.

84. Brosh R, Assia-Alroy Y, Molchadsky A, Bornstein C, Dekel E, Madar S, Shetzer Y, Rivlin N, Goldfinger N, Sarig $\mathrm{R}$, Rotter V. p53 counteracts reprogramming by inhibiting mesenchymal-to-epithelial transition. Cell death and differentiation. 2013; 20:312-320.

85. Wiman KG. p53 talks to PARP: the increasing complexity of p53-induced cell death. Cell death and differentiation. 2013; 20:1438-1439.

86. Kim OH, Lim JH, Woo KJ, Kim YH, Jin IN, Han ST, Park JW, Kwon TK. Influence of p53 and p21Waf1 expression on $\mathrm{G} 2 / \mathrm{M}$ phase arrest of colorectal carcinoma HCT116 cells to proteasome inhibitors. International journal of oncology. 2004; 24:935-941.

87. Sorrentino G, Mioni M, Giorgi C, Ruggeri N, Pinton P, Moll U, Mantovani F, Del Sal G. The prolyl-isomerase Pin1 activates the mitochondrial death program of p53. Cell death and differentiation. 2013; 20:198-208.

88. Gogna R, Madan E, Kuppusamy P, Pati U. Re-oxygenation causes hypoxic tumor regression through restoration of $\mathrm{p} 53$ wild-type conformation and post-translational modifications. Cell death \& disease. 2012; 3:e286.

89. Malek M, Guillaumot P, Huber AL, Lebeau J, Petrilli V, Kfoury A, Mikaelian I, Renno T, Manie SN. LAMTOR1 depletion induces p53-dependent apoptosis via aberrant lysosomal activation. Cell death \& disease. 2012; 3:e300.

90. Nikulenkov F, Spinnler C, Li H, Tonelli C, Shi Y, Turunen M, Kivioja T, Ignatiev I, Kel A, Taipale J, Selivanova G. Insights into p53 transcriptional function via genome-wide chromatin occupancy and gene expression analysis. Cell death and differentiation. 2012; 19:1992-2002.

91. Grizzle WE, Manne U, Weiss HL, Jhala N, Talley L. Molecular staging of colorectal cancer in African-American and Caucasian patients using phenotypic expression of $\mathrm{p} 53$, Bcl-2, MUC-1 AND p27(kip-1). International journal of cancer Journal international du cancer. 2002; 97:403-409.

92. Zalata KR, Nasif WA, Ming SC, Lotfy M, Nada NA, El-Hak NG, Leech SH. p53, Bcl-2 and C-Myc expressions in colorectal carcinoma associated with schistosomiasis in Egypt. Cellular oncology: the official journal of the International Society for Cellular Oncology. 2005; 27:245-253.

93. Demirbas S, Sucullu I, Yildirim S, Celenk T. Influence of the c-erb B-2, nm23, bcl-2 and p53 protein markers on colorectal cancer. The Turkish journal of gastroenterology: the official journal of Turkish Society of Gastroenterology. 2006; 17:13-19.

94. Colomer A, Erill N, Verdu M, Roman R, Vidal A, CordonCardo C, Puig X. Lack of p53 nuclear immunostaining is not indicative of absence of TP53 gene mutations in colorectal adenocarcinomas. Applied immunohistochemistry \& molecular morphology: AIMM / official publication of the Society for Applied Immunohistochemistry. 2003; 11:130-137. 
95. Hanel W, Marchenko N, Xu S, Yu SX, Weng W, Moll U. Two hot spot mutant p53 mouse models display differential gain of function in tumorigenesis. Cell death and differentiation. 2013; 20:898-909.

96. Celardo I, Antonov A, Amelio I, AnnicchiaricoPetruzzelli M, Melino G. p63 transcriptionally regulates the expression of matrix metallopeptidase 13. Oncotarget. 2014; 5:1279-1289.

97. Miyake M, Goodison S, Lawton A, Gomes-Giacoia E, Rosser CJ. Angiogenin promotes tumoral growth and angiogenesis by regulating matrix metallopeptidase-2 expression via the ERK1/2 pathway. Oncogene. 2014 Feb 24; doi: 10.1038/onc.2014.2. [Epub ahead of print].

98. Manzine PR, Barham EJ, Vale FA, Selistre-de-Araujo HS, Pavarini SC, Cominetti MR. Platelet a disintegrin and metallopeptidase 10 expression correlates with clock drawing test scores in Alzheimer's disease. International journal of geriatric psychiatry. 2014; 29:414-420.

99. Ortega P, Moran A, Fernandez-Marcelo T, De Juan C, Frias C, Lopez-Asenjo JA, Sanchez-Pernaute A, Torres A, Diaz-Rubio E, Iniesta P, Benito M. MMP-7 and SGCE as distinctive molecular factors in sporadic colorectal cancers from the mutator phenotype pathway. International journal of oncology. 2010; 36:1209-1215.

100. Papi A, Guarnieri T, Storci G, Santini D, Ceccarelli C, Taffurelli M, De Carolis S, Avenia N, Sanguinetti A, Sidoni A, Orlandi M, Bonafe M. Nuclear receptors agonists exert opposing effects on the inflammation dependent survival of breast cancer stem cells. Cell death and differentiation. 2012; 19:1208-1219.

101. Sunami E, Tsuno N, Osada T, Saito S, Kitayama J, Tomozawa S, Tsuruo T, Shibata Y, Muto T, Nagawa H. MMP-1 is a prognostic marker for hematogenous metastasis of colorectal cancer. The oncologist. 2000; 5:108-114.

102. Jinesh GG, Choi W, Shah JB, Lee EK, Willis DL, Kamat AM. Blebbishields, the emergency program for cancer stem cells: sphere formation and tumorigenesis after apoptosis. Cell death and differentiation. 2013; 20:382-395.

103. Sutnar A, Pesta M, Liska V, Treska V, Skalicky T, Kormunda S, Topolcan O, Cerny R, Holubec L Jr. Clinical relevance of the expression of mRNA of MMP-7, MMP-9, TIMP-1, TIMP-2 and CEA tissue samples from colorectal liver metastases. Tumour biology: the journal of the International Society for Oncodevelopmental Biology and Medicine. 2007; 28:247-252.

104. Pesta M, Holubec L Jr., Topolcan O, Cerna M, Rupert K, Holubec LS, Treska V, Kormunda S, Elgrova L, Finek J, Cerny R. Quantitative estimation of matrix metalloproteinases 2 and 7 (MMP-2, MMP-7) and tissue inhibitors of matrix metalloproteinases 1 and 2 (TIMP-1, TIMP-2) in colorectal carcinoma tissue samples. Anticancer research. 2005; 25:3387-3391.

105. Li X, Qu L, Zhong Y, Zhao Y, Chen H, Daru L. Association between promoters polymorphisms of matrix metalloproteinases and risk of digestive cancers: a metaanalysis. Journal of cancer research and clinical oncology. 2013; 139:1433-1447.

106. Pryczynicz A, Gryko M, Niewiarowska K, DymickaPiekarska V, Ustymowicz M, Hawryluk M, Cepowicz D, Borsuk A, Kemona A, Famulski W, GuzinskaUstymowicz K. Immunohistochemical expression of MMP-7 protein and its serum level in colorectal cancer. Folia histochemica et cytobiologica / Polish Academy of Sciences, Polish Histochemical and Cytochemical Society. 2013; 51:206-212.

107. Wang Z, Perez M, Caja S, Melino G, Johnson TS, Lindfors K, Griffin M. A novel extracellular role for tissue transglutaminase in matrix-bound VEGF-mediated angiogenesis. Cell death \& disease. 2013; 4:e808.

108. Schlaeppi M, Ruegg C, Tran-Thang C, Chapuis G, Tevaearai H, Lahm H, Sordat B. Role of integrins and evidence for two distinct mechanisms mediating human colorectal carcinoma cell interaction with peritoneal mesothelial cells and extracellular matrix. Cell adhesion and communication. 1997; 4:439-455.

109. Diaz-Mendoza MJ, Lorda-Diez CI, Montero JA, GarciaPorrero JA, Hurle JM. Interdigital cell death in the embryonic limb is associated with depletion of Reelin in the extracellular matrix. Cell death \& disease. 2013; 4:e800.

110. Hiebert PR, Wu D, Granville DJ. Granzyme B degrades extracellular matrix and contributes to delayed wound closure in apolipoprotein E knockout mice. Cell death and differentiation. 2013; 20:1404-1414.

111. Remy L, Trespeuch C, Bachy S, Scoazec JY, Rousselle P. Matrilysin 1 influences colon carcinoma cell migration by cleavage of the laminin-5 beta3 chain. Cancer research. 2006; 66:11228-11237.

112. Masaki T, Matsuoka H, Sugiyama M, Abe N, Goto A, Sakamoto A, Atomi Y. Matrilysin (MMP-7) as a significant determinant of malignant potential of early invasive colorectal carcinomas. British journal of cancer. 2001; 84:1317-1321.

113. Gunes M, Kemik AS, Pirincci N, Gecit I, Taken K, Yuksel MB, Kaba M, Eryilmaz R. Preoperative levels of matrix metalloproteinase-7 and -9 and tissue inhibitor of matrix metalloproteinase-1 relation to pathologic parameters in bladder carcinoma patients. Asian Pacific journal of cancer prevention: APJCP. 2013; 14:873-876.

114. Noguchi S, Yamada N, Kumazaki M, Yasui Y, Iwasaki J, Naito S, Akao Y. socs7, a target gene of microRNA-145, regulates interferon-beta induction through STAT3 nuclear translocation in bladder cancer cells. Cell death \& disease. 2013; 4:e482.

115. Abbas T, Keaton M, Dutta A. Regulation of TGF-beta signaling, exit from the cell cycle, and cellular migration through cullin cross-regulation: SCF-FBXO11 turns off CRL4-Cdt2. Cell cycle. 2013; 12:2175-2182. 
116. Meyer C, Liu Y, Kaul A, Peipe I, Dooley S. Caveolin-1 abrogates TGF-beta mediated hepatocyte apoptosis. Cell death \& disease. 2013; 4:e466.

117. Xiong L, Wen Y, Miao X, Yang Z. NT5E and FcGBP as key regulators of TGF-1-induced epithelial-mesenchymal transition (EMT) are associated with tumor progression and survival of patients with gallbladder cancer. Cell and tissue research. 2014; 355:365-374.

118. Iovino $\mathrm{S}$, Oriente $\mathrm{F}$, Botta $\mathrm{G}$, Cabaro $\mathrm{S}$, Iovane $\mathrm{V}$, Paciello O, Viggiano D, Perruolo G, Formisano P, Beguinot F. PED/PEA-15 induces autophagy and mediates TGF-beta1 effect on muscle cell differentiation. Cell death and differentiation. 2012; 19:1127-1138.

119. Marek B, Kajdaniuk D, Mazurek U, JanczewskaKazek E, Strzalka B, Beniowski M, Kos-Kudla B, Kajdaniuk J, Niedziolka D, Ostrowska Z, Borgiel-Marek H, Sieminiska L, Nowak M, Pakula D, Gatnar A, Gnot R, et al. [Quantitative assessment of mRNA TGF-betal in liver tissue in connection with serum mean daily level of TGF-1 in chronic hepatitis B patient]. Polskie Archiwum Medycyny Wewnetrznej. 2005; 114:738-745.

120. Tischner D, Wiegers GJ, Fiegl H, Drach M, Villunger A. Mutual antagonism of TGF-beta and Interleukin-2 in cell survival and lineage commitment of induced regulatory $\mathrm{T}$ cells. Cell death and differentiation. 2012; 19:1277-1287.

121. Kim SY, Jeong S, Jung E, Baik KH, Chang MH, Kim SA, Shim JH, Chun E, Lee KY. AMP-activated protein kinase-alpha1 as an activating kinase of TGF-betaactivated kinase 1 has a key role in inflammatory signals. Cell death \& disease. 2012; 3:e357.

122. Kennard S, Liu H, Lilly B. Transforming growth factorbeta (TGF- 1) down-regulates Notch3 in fibroblasts to promote smooth muscle gene expression. The Journal of biological chemistry. 2008; 283:1324-1333.

123. Her NG, Jeong SI, Cho K, Ha TK, Han J, Ko KP, Park SK, Lee JH, Lee MG, Ryu BK, Chi SG. PPARdelta promotes oncogenic redirection of TGF-betal signaling through the activation of the ABCA1-Cav1 pathway. Cell cycle. $2013 ; 12: 1521-1535$.

124. Zhou W, Fu XQ, Zhang LL, Zhang J, Huang X, Lu XH, Shen L, Liu BN, Liu J, Luo HS, Yu JP, Yu HG. The AKT1/NF-kappaB/Notch1/PTEN axis has an important role in chemoresistance of gastric cancer cells. Cell death \& disease. 2013; 4:e847.

125. Zheng Y, Zhou J, Tong Y. Gene signatures of drug resistance predict patient survival in colorectal cancer. Pharmacogenomics. 2014 Sep 2; doi: 10.1038/tpj.2014.45. [Epub ahead of print].

126. Dienstmann R, De Dosso S, Felip E, Tabernero J. Drug development to overcome resistance to EGFR inhibitors in lung and colorectal cancer. Molecular oncology. 2012; 6:15-26.
127. Ehrhardt H, Hofig I, Wachter F, Obexer P, Fulda S, Terziyska N, Jeremias I. NOXA as critical mediator for drug combinations in polychemotherapy. Cell death \& disease. 2012; 3:e327.

128. Fan CW, Chen T, Shang YN, Gu YZ, Zhang SL, Lu R, OuYang SR, Zhou X, Li Y, Meng WT, Hu JK, Lu Y, Sun XF, Bu H, Zhou ZG, Mo XM. Cancer-initiating cells derived from human rectal adenocarcinoma tissues carry mesenchymal phenotypes and resist drug therapies. Cell death \& disease. 2013; 4:e828.

129. Redmond SM, Joncourt F, Buser K, Ziemiecki A, Altermatt HJ, Fey M, Margison G, Cerny T. Assessment of P-glycoprotein, glutathione-based detoxifying enzymes and O6-alkylguanine-DNA alkyltransferase as potential indicators of constitutive drug resistance in human colorectal tumors. Cancer research. 1991; 51:2092-2097.

130. Yu R, Deedigan L, Albarenque SM, Mohr A, Zwacka RM. Delivery of sTRAIL variants by MSCs in combination with cytotoxic drug treatment leads to p53-independent enhanced antitumor effects. Cell death \& disease. 2013; 4:e503.

131. Longley DB, Allen WL, Johnston PG. Drug resistance, predictive markers and pharmacogenomics in colorectal cancer. Biochimica et biophysica acta. 2006; 1766:184-196.

132. Rapino F, Naumann I, Fulda S. Bortezomib antagonizes microtubule-interfering drug-induced apoptosis by inhibiting G2/M transition and MCL-1 degradation. Cell death \& disease. 2013; 4:e925.

133. Xu K, Liang X, Cui D, Wu Y, Shi W, Liu J. miR-1915 inhibits Bcl-2 to modulate multidrug resistance by increasing drug-sensitivity in human colorectal carcinoma cells. Molecular carcinogenesis. 2013; 52:70-78.

134. Kyula JN, Van Schaeybroeck S, Doherty J, Fenning CS, Longley DB, Johnston PG. Chemotherapy-induced activation of ADAM-17: a novel mechanism of drug resistance in colorectal cancer. Clinical cancer research: an official journal of the American Association for Cancer Research. 2010; 16:3378-3389.

135. Bartucci M, Svensson S, Romania P, Dattilo R, Patrizii M, Signore M, Navarra S, Lotti F, Biffoni M, Pilozzi E, Duranti E, Martinelli S, Rinaldo C, Zeuner A, MaugeriSacca M, Eramo A, et al. Therapeutic targeting of Chk1 in NSCLC stem cells during chemotherapy. Cell death and differentiation. 2012; 19:768-778.

136. Fan CW, Fan HA, Hsu SH, Chan CC, Chen SY, Hsu YH, Chan EC. An in vitro short time-high dose drug exposure assay for predicting 5FU-resistance of colorectal cancer. Cancer letters. 2004; 214:181-188.

137. Guido C, Whitaker-Menezes D, Capparelli C, Balliet R, Lin Z, Pestell RG, Howell A, Aquila S, Ando S, MartinezOutschoorn U, Sotgia F, Lisanti MP. Metabolic reprogramming of cancer-associated fibroblasts by TGF-beta drives tumor growth: connecting TGF-beta signaling with 
"Warburg-like" cancer metabolism and L-lactate production. Cell cycle. 2012; 11:3019-3035.

138. Gogineni VR, Gupta R, Nalla AK, Velpula KK, Rao JS. UPAR and cathepsin B shRNA impedes TGF-betal-driven proliferation and invasion of meningioma cells in a XIAPdependent pathway. Cell death \& disease. 2012; 3:e439.

139. Calon A, Espinet E, Palomo-Ponce S, Tauriello DV, Iglesias M, Cespedes MV, Sevillano M, Nadal C, Jung P, Zhang XH, Byrom D, Riera A, Rossell D, Mangues R, Massague J, Sancho E, et al. Dependency of colorectal cancer on a TGF-beta-driven program in stromal cells for metastasis initiation. Cancer cell. 2012; 22:571-584.

140. Lee J, Choi JH, Joo CK. TGF-betal regulates cell fate during epithelial-mesenchymal transition by upregulating survivin. Cell death \& disease. 2013; 4:e714.

141. Chen Y, Xiao Y, Ge W, Zhou K, Wen J, Yan W, Wang Y, Wang B, Qu C, Wu J, Xu L, Cai W. miR-200b inhibits TGF-beta1-induced epithelial-mesenchymal transition and promotes growth of intestinal epithelial cells. Cell death \& disease. 2013; 4:e541.

142. Shen A, Lin W, Chen Y, Liu L, Chen H, Zhuang Q, Lin J, Sferra TJ, Peng J. Pien Tze Huang inhibits metastasis of human colorectal carcinoma cells via modulation of TGF-beta1/ZEB/miR200 signaling network. International journal of oncology. 2014 November 24; 685-690 doi: 10.3892/ijo.2014.2772. [Epub ahead of print].

143. Tirino V, Camerlingo R, Bifulco K, Irollo E, Montella R, Paino F, Sessa G, Carriero MV, Normanno N, Rocco G, Pirozzi G. TGF-beta1 exposure induces epithelial to mesenchymal transition both in CSCs and non-CSCs of the A549 cell line, leading to an increase of migration ability in the CD133+ A549 cell fraction. Cell death \& disease. 2013; 4:e620.

144. Ziselman EM, Harkavy SE, Hogan M, West W, Atkinson B. Peritoneal washing cytology. Uses and diagnostic criteria in gynecologic neoplasms. Acta cytologica. 1984; 28:105-110.

145. Ananthakrishnan AN, Hoffmann RG, Saeian K. Higher physician density is associated with lower incidence of late-stage colorectal cancer. Journal of general internal medicine. 2010; 25:1164-1171.

146. Katoh H, Yamashita K, Wang G, Sato T, Nakamura T, Watanabe M. Anastomotic leakage contributes to the risk for systemic recurrence in stage II colorectal cancer. Journal of gastrointestinal surgery: official journal of the Society for Surgery of the Alimentary Tract. 2011; 15:120-129.

147. Wang C, Lv X, He C, Hua G, Tsai MY, Davis JS. The G-protein-coupled estrogen receptor agonist G-1 suppresses proliferation of ovarian cancer cells by blocking tubulin polymerization. Cell death \& disease. 2013; 4:e869.

148. Huang L, Wang HY, Li JD, Wang JH, Zhou Y, Luo RZ, Yun JP, Zhang Y, Jia WH, Zheng M. KPNA2 promotes cell proliferation and tumorigenicity in epithelial ovarian carcinoma through upregulation of c-Myc and downregulation of FOXO3a. Cell death \& disease. 2013; 4:e745.

149. Reggiani Bonetti L, Di Gregorio C, De Gaetani C, Pezzi A, Barresi G, Barresi V, Roncucci L, Ponz de Leon M. Lymph node micrometastasis and survival of patients with Stage I (Dukes' A) colorectal carcinoma. Scandinavian journal of gastroenterology. 2011; 46:881-886.

150. Wong KP, Poon JT, Fan JK, Law WL. Prognostic value of lymph node ratio in stage III colorectal cancer. Colorectal disease: the official journal of the Association of Coloproctology of Great Britain and Ireland. 2011; 13:1116-1122.

151. Wu X, Wang B, Dong Z, Zhou S, Liu Z, Shi G, Cao Y, $\mathrm{Xu}$ Y. A NANOS3 mutation linked to protein degradation causes premature ovarian insufficiency. Cell death \& disease. 2013; 4:e825.

152. Toiyama Y, Miki C, Inoue Y, Tanaka K, Mohri Y, Kusunoki M. Evaluation of an inflammation-based prognostic score for the identification of patients requiring postoperative adjuvant chemotherapy for stage II colorectal cancer. Experimental and therapeutic medicine. 2011; 2:95-101.

153. Wang W, Tang Y, Ni L, Kim E, Jongwutiwes T, Hourvitz A, Zhang R, Xiong H, Liu HC, Rosenwaks Z. Overexpression of Uromodulin-like1 accelerates follicle depletion and subsequent ovarian degeneration. Cell death \& disease. 2012; 3:e433.

154. Bosanquet DC, Harris DA, Evans MD, Beynon J. Systematic review and meta-analysis of intraoperative peritoneal lavage for colorectal cancer staging. The British journal of surgery. 2013; 100:853-862.

155. Marutsuka T, Shimada S, Shiomori K, Hayashi N, Yagi Y, Yamane T, Ogawa M. Mechanisms of peritoneal metastasis after operation for non-serosa-invasive gastric carcinoma: an ultrarapid detection system for intraperitoneal free cancer cells and a prophylactic strategy for peritoneal metastasis. Clinical cancer research: an official journal of the American Association for Cancer Research. 2003; 9:678-685.

156. Kodera Y, Nakanishi H, Ito S, Yamamura Y, Fujiwara M, Koike M, Hibi K, Ito K, Tatematsu M, Nakao A. Prognostic significance of intraperitoneal cancer cells in gastric carcinoma: detection of cytokeratin $20 \mathrm{mRNA}$ in peritoneal washes, in addition to detection of carcinoembryonic antigen. Gastric cancer: official journal of the International Gastric Cancer Association and the Japanese Gastric Cancer Association. 2005; 8:142-148.

157. Vogel I, Kruger U, Marxsen J, Soeth E, Kalthoff H, Henne-Bruns D, Kremer B, Juhl H. Disseminated tumor cells in pancreatic cancer patients detected by immunocytology: a new prognostic factor. Clinical cancer research: an official journal of the American Association for Cancer Research. 1999; 5:593-599. 
158. Kim SJ, Widenmaier SB, Choi WS, Nian C, Ao Z, Warnock G, McIntosh CH. Pancreatic beta-cell prosurvival effects of the incretin hormones involve post-translational modification of Kv2.1 delayed rectifier channels. Cell death and differentiation. 2012; 19:333-344.

159. Hara M, Nakanishi H, Jun Q, Kanemitsu Y, Ito S, Mochizuki Y, Yamamura Y, Kodera Y, Tatematsu M, Hirai T, Kato T. Comparative analysis of intraperitoneal minimal free cancer cells between colorectal and gastric cancer patients using quantitative RT-PCR: possible reason for rare peritoneal recurrence in colorectal cancer. Clinical \& experimental metastasis. 2007; 24:179-189.

160. Abu-Hijleh MF, Habbal OA, Moqattash ST. The role of the diaphragm in lymphatic absorption from the peritoneal cavity. Journal of anatomy. 1995; 186:453-467.

161. Zhang YM, Dai BL, Zheng L, Zhan YZ, Zhang J, Smith WW, Wang XL, Chen YN, He LC. A novel angiogenesis inhibitor impairs lovo cell survival via targeting against human VEGFR and its signaling pathway of phosphorylation. Cell death \& disease. 2012; 3:e406.

162. Lloyd JM, McIver CM, Stephenson SA, Hewett PJ, Rieger N, Hardingham JE. Identification of early-stage colorectal cancer patients at risk of relapse post-resection by immunobead reverse transcription-PCR analysis of peritoneal lavage fluid for malignant cells. Clinical cancer research: an official journal of the American Association for Cancer Research. 2006; 12:417-423.

163. Kumar S, Guru SK, Pathania AS, Kumar A, Bhushan S, Malik F. Autophagy triggered by magnolol derivative negatively regulates angiogenesis. Cell death \& disease. 2013; 4:e889.

164. Schott A, Vogel I, Krueger U, Kalthoff H, Schreiber HW, Schmiegel W, Henne-Bruns D, Kremer B, Juhl H. Isolated tumor cells are frequently detectable in the peritoneal cavity of gastric and colorectal cancer patients and serve as a new prognostic marker. Annals of surgery. 1998; 227:372-379.

165. Mohan HM, O'Connor DB, O'Riordan JM, Winter DC. Prognostic significance of detection of microscopic peritoneal disease in colorectal cancer: a systematic review. Surgical oncology. 2013; 22:e1-6.

166. Ambrose NS, MacDonald F, Young J, Thompson H, Keighley MR. Monoclonal antibody and cytological detection of free malignant cells in the peritoneal cavity during resection of colorectal cancer-can monoclonal antibodies do better? European journal of surgical oncology: the journal of the European Society of Surgical Oncology and the British Association of Surgical Oncology. 1989; 15:99-102.

167. Leather AJ, Kocjan G, Savage F, Hu W, Yiu CY, Boulos PB, Northover JM, Phillips RK. Detection of free malignant cells in the peritoneal cavity before and after resection of colorectal cancer. Diseases of the colon and rectum. 1994; 37:814-819.

168. Gu X, Xing L, Shi G, Liu Z, Wang X, Qu Z, Wu X, Dong Z, Gao X, Liu G, Yang L, Xu Y. The circadian mutation PER2(S662G) is linked to cell cycle progression and tumorigenesis. Cell death and differentiation. 2012; 19:397-405.

169. Cregger M, Berger AJ, Rimm DL. Immunohistochemistry and quantitative analysis of protein expression. Archives of pathology \& laboratory medicine. 2006; 130:1026-1030.

170. Biesterfeld S, Veuskens U, Schmitz FJ, Amo-Takyi B, Bocking A. Interobserver reproducibility of immunocytochemical estrogen- and progesterone receptor status assessment in breast cancer. Anticancer research. 1996; 16:2497-2500.

171. Harris DA, Beynon J. Superstaging in colorectal cancer. The British journal of surgery. 2012; 99:883-884.

172. Goldberg L, Israeli R, Kloog Y. FTS and 2-DG induce pancreatic cancer cell death and tumor shrinkage in mice. Cell death \& disease. 2012; 3:e284.

173. Yonemura Y, Fujimura T, Ninomiya I, Kim BS, Bandou E, Sawa T, Kinoshita K, Endo Y, Sugiyama K, Sasaki T. Prediction of peritoneal micrometastasis by peritoneal lavaged cytology and reverse transcriptasepolymerase chain reaction for matrix metalloproteinasemRNA. Clinical cancer research: an official journal of the American Association for Cancer Research. 2001; 7:1647-1653.

174. Celardo I, Grespi F, Antonov A, Bernassola F, Garabadgiu AV, Melino G, Amelio I. Caspase-1 is a novel target of p63 in tumor suppression. Cell death \& disease. 2013; 4:e645.

175. Amelio I, Markert EK, Rufini A, Antonov AV, Sayan BS, Tucci P, Agostini M, Mineo TC, Levine AJ, Melino G. p73 regulates serine biosynthesis in cancer. Oncogene. 2014 Oct 16; 33:5039-5046, doi: 10.1038/ onc.2013.456. 